\title{
Blurred Lines: The Ethics and Policy of Greenhouse Gas Removal at Scale
}

\author{
Emily M. Cox ${ }^{1,2 *}$, Nick Pidgeon ${ }^{1,2}$, Elspeth Spence ${ }^{1,2}$ and Gareth Thomas ${ }^{1}$ \\ ${ }^{1}$ Understanding Risk Group, Department of Psychology, Cardiff University, Cardiff, United Kingdom, ${ }^{2}$ Leverhulme Centre for \\ Climate Change Mitigation, University of Sheffield, Sheffield, United Kingdom
}

OPEN ACCESS

Edited by:

William C. Burns,

Forum for Climate Engineering

Assessment, School of International

Service, American University,

United States

Reviewed by:

David Morrow,

American University, United States

Xander Wang

University of Louisiana at Lafayette,

United States

*Correspondence:

Emily M. Cox

coxe3@cardiff.ac.uk

Specialty section:

This article was submitted to Interdisciplinary Climate Studies,

a section of the journal

Frontiers in Environmental Science

Received: 12 December 2017

Accepted: 11 May 2018

Published: 29 May 2018

Citation:

Cox EM, Pidgeon N, Spence E and Thomas G (2018) Blurred Lines: The Ethics and Policy of Greenhouse Gas

Removal at Scale.

Front. Environ. Sci. 6:38.

doi: 10.3389/fenvs.2018.00038
The topic of Greenhouse Gas Removal (GGR) for climate geoengineering is becoming increasingly salient following the IPCC's 5th Assessment Report and the Paris Agreement. GGR is thought of as a separate category to mitigation techniques such as low-carbon supply or demand reduction, yet multiple social, ethical and acceptability concerns cut across categories. We propose moving beyond classifying climate strategies as a set of discrete categories (which may implicitly homogenize diverse technologies), toward a prioritization of questions of scale of both technology and decision-making in the examination of social and ethical risks. This is not just a theoretical issue: important questions for policy, governance and finance are raised, for instance over the future inclusion of GGR in carbon markets. We argue that the conclusions drawn about how best to categorize, govern and incentivize any strategy will depend on the framing used, because different framings could lead to very different policy recommendations being drawn. Because of this, a robust approach to developing, governing and financing GGR should pay attention first to urgent concerns regarding democracy, justice and acceptability.

Keywords: geoengineering, greenhouse gas removal, ethics, acceptability, risk, policy

\section{INTRODUCTION}

The topic of geoengineering- "The deliberate, large-scale manipulation of the planetary environment in order to counteract anthropogenic climate change" (Royal Society, 2009 p. 1)has been climbing up the scientific and political agenda in recent decades. The Royal Society's (2009) report on geoengineering distinguished between Solar Radiation Management (SRM, which aims to reflect a small percentage of the sun's light and heat back into space) and Greenhouse Gas Removal (GGR, which aims to remove greenhouse gases from the atmosphere). Until recently, most discussions on the social and ethical aspects of geoengineering have focused on SRM. However, in the wake of the Paris Agreement and the IPCC's 5th Assessment report, the idea of "negative emissions" is becoming increasingly salient (Fuss et al., 2014); accordingly, questions are being raised regarding the social, ethical and policy implications of GGR (Table 1 gives an overview of major GGR technologies).

As a starting point, it may not make sense to discuss diverse technologies under a blanket term such as "geoengineering" (Olson, 2012; Bellamy et al., 2013; Cairns and Stirling, 2014; Asayama et al., 2017); in fact, Bellamy and Lezaun (2017) posit that recent discourses have deliberately sought to "unframe" geoengineering as a distinct object of debate. Heyward (2013) offers a useful typology for understanding different categories of response to climate change (Table 2); GGR and mitigation both seek to reduce atmospheric concentrations of Greenhouse Gases (GHGs), 
TABLE 1 | Some major GGR proposals.

\begin{tabular}{|c|c|c|}
\hline Method & Description & Concerns \\
\hline Afforestation/reforestation & Planting trees or reforesting previously deforested areas & $\begin{array}{l}\text { - Land-use conflicts between reforestation and agriculture } \\
\text { - Carbon stored in vegetation can easily be released by } \\
\text { fire, drought or deliberate deforestation }\end{array}$ \\
\hline Soil Carbon Sequestration (SCS) & $\begin{array}{l}\text { Changing land management and farming practices to } \\
\text { increase the carbon content of soil }\end{array}$ & $\begin{array}{l}\text { - Soils eventually reach saturation } \\
\text { - Vulnerable to disturbance (e.g., later land-use changes) } \\
\text { - May increase release of other greenhouse gases from } \\
\text { soil, e.g., NOx }\end{array}$ \\
\hline Wetland restoration & $\begin{array}{l}\text { Restoring or constructing carbon-dense ecosystems } \\
\text { such as wetlands, peatlands and coastal ecosystems. }\end{array}$ & $\begin{array}{l}\text { - Increased production of non- } \mathrm{CO}_{2} \text { gases such as } \\
\text { methane } \\
\text { - Relatively limited global sequestration potential } \\
\text { - Competition for land }\end{array}$ \\
\hline $\begin{array}{l}\text { Bioenergy with Carbon Capture } \\
\text { and Sequestration (BECCS) }\end{array}$ & $\begin{array}{l}\text { Biomass used as fuel for electricity generation or } \\
\text { hydrogen production, with Carbon Capture and Storage } \\
\text { (CCS) of the resulting } \mathrm{CO}_{2}^{\mathrm{a}}\end{array}$ & $\begin{array}{l}\text { - Fuel vs. food: incentive for biomass production can } \\
\text { reduce the availability and increase the cost of food crops } \\
\text { - Environmental impacts of intensive growing } \\
\text { - Availability and safety of sequestration sites }\end{array}$ \\
\hline Biochar & $\begin{array}{l}\text { Agricultural and forestry wastes burned through pyrolysis } \\
\text { to produce biochar (charcoal), which is sequestered in } \\
\text { the soil. }\end{array}$ & $\begin{array}{l}\text { - Supply of biomass wastes } \\
\text { - Long-term impacts of high biochar applications not yet } \\
\text { known }\end{array}$ \\
\hline $\begin{array}{l}\text { Terrestrial Enhanced Weathering } \\
(\mathrm{EW})\end{array}$ & $\begin{array}{l}\text { Rock weathering processes accelerated by finely } \\
\text { crushing rocks and spreading them on agricultural soils. } \\
\text { Rocks weather to produce carbonates, which sink into } \\
\text { the deep ocean, sequestering the carbon they contain. }\end{array}$ & $\begin{array}{l}\text { - Requires mining, processing and transportation of large } \\
\text { quantities of crushed rock, with high energy use and costs } \\
\text { - Uncertainties about impacts on soil pH and vegetation } \\
\text { - Possible leaching of heavy metals into soils and crops }\end{array}$ \\
\hline Direct Air Capture (DAC) & $\begin{array}{l}\text { Industrial processes to extract } \mathrm{CO}_{2} \text { from ambient air for } \\
\text { sequestration. }\end{array}$ & $\begin{array}{l}\text { - Technically feasible, but not clear if cost effective } \\
\text { processes can be developed } \\
\text { - Availability and safety of sequestration sites }\end{array}$ \\
\hline Ocean Fertilisation & $\begin{array}{l}\text { Adding iron, nitrogen or phosphates to ocean water as } \\
\text { nutrients to stimulate the growth of phytoplankton that } \\
\text { absorb } \mathrm{CO}_{2} \text { during photosynthesis. Some of this organic } \\
\text { matter sinks into the deep ocean, sequestering the } \\
\text { carbon it contains. }\end{array}$ & $\begin{array}{l}\text { - Potential disruption of the ocean carbon system } \\
\text { - May increase "dead zones" of the ocean } \\
\text { - Not as effective as hoped for removing carbon }\end{array}$ \\
\hline
\end{tabular}

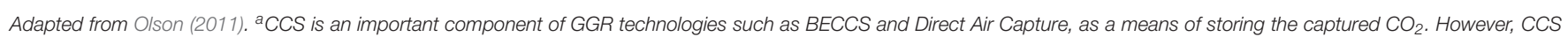
does not always result in net negative emissions: for example, on a fossil fuel plant CCS reduces the $\mathrm{CO}_{2}$ emitted and is therefore best thought of as mitigation technology.

but GGR removes previously-emitted GHGs from the earth system, whereas mitigation seeks to avoid the emissions in the first place. However, complications with these definitions soon arise elsewhere, with the UNFCCC classing the enhancement of carbon sinks as mitigation (United Nations, 1992), and the Convention on Biological Diversity stating that some GGR techniques such as afforestation "are also considered climate mitigation techniques" (Williamson and Bodle, 2016 p. 8). In fact, (Lomax et al., 2015b p. 126) argue that the distinction between GGR and mitigation is "in many ways artificial and is an unconstructive basis for developing effective policy". Meanwhile Scheer and Renn (2014), in an exploration of experts' views, find that considerable similarities are drawn between geoengineering and certain contentious mitigation options such as nuclear power.

In this article we examine some of the social, ethical and acceptability concerns which have been raised over geoengineering, and look at them in the light of various GGR and mitigation strategies, to highlight the considerable overlap between categories. This is important for two reasons: firstly, because most of the literature on GGR focuses on economic and technical feasibility, without considering social barriers (Buck, 2016); and secondly, because this issue raises important practical questions regarding the governance and financing of climate engineering techniques. Section Social, Ethical, and Political Concerns examines three important ethical themes which whilst typically raised about geoengineering can also apply to many mitigation technologies, and demonstrates that several technologies exist in a sort of ethical "gray area" between the two. On the basis of this, we propose moving beyond classifying climate strategies as a set of discrete categories, toward a prioritization of questions of scale (of both technology and decision-making) in the examination of social and ethical risks. In section Discussion we then examine the policy and governance implications of this proposal, arguing that there is so single "desirable" way of categorizing, governing or incentivizing GGR, because it depends on how the problem and the technology is framed. Nevertheless, it becomes clear that the ethical development of any technologically-advanced climate strategy needs to urgently address concerns regarding democracy, justice and acceptability. 
TABLE 2 | A typology of five climate strategies (adapted from Heyward, 2013).

\begin{tabular}{|c|c|c|c|c|c|}
\hline \multirow{2}{*}{$\begin{array}{l}\text { Aim } \\
\\
\text { Strategy }\end{array}$} & \multicolumn{2}{|c|}{$\begin{array}{l}\text { Avoiding a given level of } \\
\text { atmospheric GHG concentration }\end{array}$} & \multirow{2}{*}{$\begin{array}{l}\text { Avoiding global average } \\
\text { temperature increases } \\
\text { Solar Radiation } \\
\text { Management (SRM) } \\
\text { Increasing albedo }\end{array}$} & \multirow{2}{*}{$\begin{array}{l}\text { Ensuring that rising } \\
\text { temperatures do not impact } \\
\text { upon core interests } \\
\text { Adaptation } \\
\text { Reducing the impacts of high } \\
\text { atmospheric GHG concentration }\end{array}$} & \multirow{2}{*}{$\begin{array}{l}\text { Providing redress for } \\
\text { injuries to core } \\
\text { interests }\end{array}$} \\
\hline & $\begin{array}{l}\text { Mitigation } \\
\text { Reducing GHG } \\
\text { emissions }\end{array}$ & $\begin{array}{l}\text { Greenhouse Gas } \\
\text { Removal (GGR) } \\
\text { Drawing GHGs out of } \\
\text { the atmosphere }\end{array}$ & & & \\
\hline Examples & $\begin{array}{l}\text { Wind turbines; } \\
\text { Electric Vehicles; } \\
\text { Energy demand } \\
\text { reduction }\end{array}$ & $\begin{array}{l}\text { Afforestation, } \\
\text { BECCS; Enhanced } \\
\text { Weathering }\end{array}$ & $\begin{array}{l}\text { Stratospheric Aerosol } \\
\text { Injection; Mirrors in space }\end{array}$ & $\begin{array}{l}\text { Improved irrigation; Flood } \\
\text { defenses; Protection against } \\
\text { disease }\end{array}$ & $\begin{array}{l}\text { Compensating flood } \\
\text { victims; Suing } \\
\text { high-emitting } \\
\text { governments }\end{array}$ \\
\hline
\end{tabular}

\section{SOCIAL, ETHICAL, AND POLITICAL CONCERNS}

\section{Treating the Symptoms?}

A common critique of geoengineering is that unlike mitigation it merely treats the symptoms of climate change rather than reducing the cause (i.e., high concentrations of atmospheric GHGs) (Anshelm and Hansson, 2014; ETC Group Heinrich Böll Foundation, 2017; Wibeck et al., 2017). However, GGR draws GHGs out of the atmosphere after they are emitted, thus raising the question of whether it treats the symptoms or the cause. In fact, Ipsos Mori (2010) controversially presented GGR as "addressing the root cause" of climate change (cf. Corner et al., 2011); however, if we take the cause of climate change to be the irresponsible burning of fossil fuels, GGR may be viewed as another treatment of symptoms which still fails to address unsustainable patterns of production and consumption (Hamilton, 2010; Stirling, 2014; Anderson, 2015). This issue is important from a justice perspective, because a technology which supports incumbent systems might also perpetuate existing inequalities. Gardiner (2010) argues that it is unjust for Western elites responsible for high emissions to call for a techno-fix which doesn't address underlying systems of inequality. For example, some GGR proposals, such as biomass with carbon capture (BECCS) and Enhanced Weathering (EW), could require large amounts of land in tropical areas with historically low emissions, and there are understandable concerns regarding how fair this would be on the local inhabitants (McLaren, 2016; Lawford-Smith and Currie, 2017). Temporal justice is also potentially a problem: both GGR and SRM arouse questions of intergenerational equity (Wong, 2014), because assuming that we can emit what we like now and simply rely on negative emissions later may constitute an unacceptable transfer of risk onto future generations (Hansen et al., 2017; Lawford-Smith and Currie, 2017; Shue, 2017).

Concern over techno-fixes is not exclusively the domain of geoengineering: many mitigation options have been critiqued on the same grounds, especially large supply-side proposals such as nuclear power or big hydroelectric dams. In fact, for BECCS, the majority of equity concerns actually relate to the mitigation technology (the biomass) rather than the carbon removal technology. Some GGR proposals might impact oceans or waterways (e.g., EW, Ocean Fertilization), and concerns are similar for any mitigation strategy which impacts water ecosystems and communities relying on them. It could be argued that even demand-side mitigation is not immune to equity and justice problems, because the middle classes in emerging economies will probably be responsible for considerable energy demand growth in the future (particularly from difficult-todecarbonize sectors such as aviation and meat consumption), and it may be ethically challenging to dictate that these emerging middle classes must now alter their diets or avoid foreign holidays because of historical emissions in Western nations.

Each of the climate strategies described above are largescale, requiring large infrastructural, environmental or societal alteration. Many mitigation techniques can be carried out on a small-scale, thus engendering fewer equity and justice issues; the problems only start emerging when the scale is increased. For example, there are few equity challenges associated with small solar co-operatives or domestic micro-generation, but it's not difficult to envisage the potential social and ecosystem impacts of huge solar electricity export projects such as "Desertec" in North Africa. Similarly, micro-hydro schemes will usually be less problematic than big dams, as evidenced by comparing the Three Gorges Dam to any number of micro-hydro projects in China. It could be the same for GGR: a salient example is afforestation, which on a small scale can create co-benefits, but on a larger scale has been implicated in land-grabbing and biodiversity loss (Cotula, 2009; Fleurke, 2013), for example in the case of the New Forests Company which displaced more than 15,000 people in Uganda to plant trees (Grainger and Geary, 2011). More technologically-advanced proposals such as EW and Direct Air Capture (DAC) could also be carried out on a very small scale; but similarly to mitigation, small-scale projects may struggle to benefit from economies of scale, and they will (individually) result in smaller GHG reductions.

\section{Democracy and Plurality}

Connected to questions of justice are concerns about democracy and who makes the decisions regarding the world that we live in. Gardiner (2010) argues that geoengineering would affect everyone, therefore it's unjust for decisions to be left up to elites or "experts." Certainly, at present, most geoengineering activities are carried out in a very centralized and top-down 
manner, and the term "Geoclique" has even been used to describe the small group of (mainly white, male) proponents of geoengineering (Porter and Hulme, 2013; Buck et al., 2014). Stirling (2014) argues that the very concept of geoengineering automatically assumes control of earth systems by one small group of people. For example, climate change institutions such as the IPCC and UNFCCC recommend GGR on the basis of Integrated Assessment Models which show that it is needed to avoid catastrophic climate change; yet that entire proposition, including the institutions and experts involved, the models and methods used, and the framings employed ("necessity," "catastrophe") have all been determined in a rather exclusive manner. Of course, many mitigation projects and decisions are also carried out in a centralized and non-participatory way, but proponents of more radical emissions reductions would argue that we need a societal transformation away from such top-down decision-making, which may be incompatible with expensive, technologically-advanced GGR proposals (McLaren, 2016).

Public perceptions and the "acceptability" of GGR are likely to be just as important as technological and economic feasibility (Corner and Pidgeon, 2010; Beerling, 2017). Risk frames are central to understanding social context, and whether GGR is framed as a climate mitigation strategy or part of geoengineering will likely influence how these technologies are interpreted. Support is also likely to be conditional (Pidgeon and Spence, 2017), as well as being correlated with people's underlying values (Corner and Pidgeon, 2014; Gregory et al., 2016). Similar characteristics of conditional acceptance and ambivalence have been identified for many mitigation options such as nuclear power (Bickerstaff et al., 2008), and for public attitudes toward low-carbon energy systems more generally (Corner and Pidgeon, 2010; Demski et al., 2015). Under such circumstances it is less important to ask whether any technology is in some way "acceptable" or not, but rather to identify the conditions under which a project or scheme might in the future become acceptable for most people (Pidgeon and Demski, 2012). Importantly, for most risky technologies, perceptions and acceptability are both complex (Pidgeon et al., 1992; Devine-Wright, 2009; Persson et al., 2015) and can be subject to dynamic change (Pidgeon et al., 2003). For example, Lin (2013) demonstrates that previously taboo subjects can quickly become normalized: the idea of climate adaptation, which is now a central goal of global climate policy and is seen as imperative to redress the inequities of climate impacts, was once considered morally problematic for many of the same reasons as geoengineering.

\section{Mitigation Deterrence}

One of the major arguments against geoengineering is that it could reduce incentives for stringent mitigation (Hamilton, 2010; Corner and Pidgeon, 2014; McLaren et al., 2016; Campbell-Arvai et al., 2017). If this were the case for GGR, future generations could be responsible for maintaining projects indefinitely, as GGR won't address the underlying causes of unsustainable fossil fuel combustion (Jamieson, 2013; Preston, 2013, 2016; Wong, 2014; Lawford-Smith and Currie, 2017). As stated by
(Wong (2014) p. 190), GGR should be seen not as a oneoff event, but as a "temporally-extended process." Although empirical work on the mitigation deterrence effects of GGR is ongoing (see for example Markusson et al., 2017), it is clear that the concept of GGR has created a unique framing of climate strategy which relies heavily on novel technologies which do not yet exist at scale (Anderson and Peters, 2016). However, these issues could also apply to mitigation options such as nuclear power and fossil CCS, which are widely agreed not to qualify as geoengineering, but experience similar concerns regarding lock-in and mitigation deterrence (Unruh and Carrillo-Hermosilla, 2006; Markusson and Haszeldine, 2009; Lee and Gloaguen, 2015). For example, McLaren et al. (2013) describe evidence for a policy preference for CCS over other means of reducing emissions in multiple OECD countries and US states; they argue that alongside the failure of demonstration projects such as Longannet in Scotland, this has resulted in overreliance on CCS, thus increasing climate change risk via the same mechanisms as overreliance on GGR in climate policy. Clearly, the failure of rapid CCS development provides important lessons for novel GGR, yet also reveals the complexities behind proposals to "focus on reducing emissions first and foremost"; we shall return to this topic in the next section.

\section{DISCUSSION}

\section{A Question of Scale}

The preceding text demonstrates that in social and ethical terms, the boundaries between GGR and mitigation are blurred. It has also indicated that scale (of both the technology and the decision-making) is an important factor in determining social and ethical risks, because many climate strategies are relatively innocuous at small scale, but could be problematic at a larger scale. This is obviously the case for large-scale supply-side mitigation technologies such as nuclear and large hydro, and perhaps also for large-scale energy demand reduction which itself is not immune to ethical problems. The Convention on Biological Diversity actually states that GGR on a small enough scale doesn't count as geoengineering (Williamson and Bodle, 2016); given this confusion even in the policy literature, it is worth emphasizing that scale is complex and subjective (Bellamy et al., 2017). For example, a distinction can be made between "research" and "deployment," with studies showing that the general public are generally more supportive of research than deployment (Pidgeon and Spence, 2017); however, accurately researching complex earth system interactions is near impossible in a contained environment, and the line between "research" and "deployment" becomes increasingly blurred when research moves from the lab into a field trial (Tedsen and Homann, 2013). As shown by Bellamy et al. (2017), more nuanced conceptions of scale such as "controllability" and "reversibility" are likely to be far better predictors of the acceptability of geoengineering activities than simple technologically-determined conceptions of scale such as "research vs. deployment" or "large vs small." Moreover, scale is clearly not the only determinant of potential social and ethical 
issues: for example, the same technology, implemented at the same scale but in different locations, could experience quite different issues (cf. Devine-Wright, 2011; Cohen et al., 2014; Gannon and Hulme, 2017).

Fundamental to this entire discussion is the way in which the risks, benefits and scale of GGR are framed, because assessments of risks are dependent on the framing of assumptions, especially in the context of deep uncertainty or ignorance (Stirling, 2010; Stilgoe et al., 2013). For example, framing something as a "technology," a "proposal" or a "risk" has important implications for its tangibility and perceived efficacy (Henwood et al., 2008; Bellamy and Lezaun, 2017). Similarly, framing a project as "mitigation" or "small-scale" immediately portrays it in a certain light, despite the considerable classification complexities discussed throughout this paper. There is an extensive literature on the framing of risks and benefits in relation to climate engineering, which there is not scope here to explore in detail (cf. Markusson, 2013; Porter and Hulme, 2013; Cairns and Stirling, 2014; Preston, 2015; McLaren, 2016; Bellamy and Lezaun, 2017); but we shall discuss some of the implications of risk framings in the following section.

\section{Implications for Policy and Governance}

We have argued that the line between GGR and mitigation is complex, blurred, and depends on the technology and the scale at which it's being implemented. But what practical implications does this have? In fact, this question is extremely important for policy-making on GGR, especially regarding finance and incentives. Large-scale afforestation is already eligible for carbon permits under the Clean Development Mechanism, therefore this finance route may be proposed for more technologically-advanced GGR such as DAC and EW (Meadowcroft, 2013; Lomax et al., 2015a). Yet some GGRs are already included in countries' national mitigation targets and Nationally Determined Contributions, which means that care needs to be taken to avoid double-counting of limited resources such as available land. It could be argued that policy may be experiencing a sort of "slippery slope" between mitigation and GGR, which decision-makers need to be aware of when dealing with the complexities which will doubtless arise when dealing with novel GGR at scale. Discussion of GGR is often accompanied by sensible reminders to focus on mitigation first and foremost (e.g., EASAC, 2018); however, in the existence of such blurred boundaries, this needs ongoing examination of what it means to do "mitigation first," and whether this implies halting the implementation of GGRs such as wetland restoration and afforestation. To an extent, a case-by-case approach is needed, in terms of both the technology and the scale of implementation and impacts, as well as other important considerations such as location. A portfolio of measures will be needed to address climate change, because of limitations to individual technologies and the importance of diversity for minimizing risk under conditions of deep uncertainty; the challenge (and the subject of ongoing work) will be to work out what that portfolio might look like, particularly in terms of the techno-economic, social and ethical interactions between technologies.
Importantly, as discussed in the previous section, the conclusions drawn about how best to categorize, govern and incentivize any strategy will depend on the framing used. For example, if the arguments posed in this paper were framed as indicating a "slippery slope" between GGR and mitigation, this could lead to a conclusion that GGR is in some way unique and that therefore the distinction should be cemented before the slope becomes too steep. On the other hand, an opposing framing could lead to a conclusion that GGR is simply a corollary of mitigation measures already in place, and that therefore the two should be pursued with equal vigor. Rather than argue for either of these propositions, we propose taking the discussion back a step, to acknowledge the points made in section Social, Ethical, and Political Concerns-that large-scale technological climate strategies are often fraught with concerns regarding democracy, justice and acceptability. Therefore, if GGR projects and proposals are to be pursued, care needs to be taken to make the process more democratic. One way of doing this could be to support deliberative processes which allow a diverse range of groups (including non-experts and affected parties) to participate, not only in governance decisions, but in the very co-creation of novel technologies and the narratives and framings by which they are discussed.

\section{CONCLUSION}

This article has explored social and ethical concerns arising in the literature on geoengineering, focusing on topics of democracy and plurality, mitigation deterrence, and the ability to treat the root cause of climate change. Using examples of particular technologies and proposals, we have sought to demonstrate that, in social and ethical terms at least, the boundaries between GGR and mitigation are rather blurred. Of course, it is often the case that diverse categories of technologies have overlapping ethical concerns; however, the ethics of GGR and mitigation is a particularly salient topic at this point in time, due to the sheer scale at which GGR is employed in many climate mitigation projections. This has led to sensible reminders to focus on mitigation first and foremost, yet in the existence of such blurred boundaries there is a need to be clear about what exactly this entails.

We have argued that the scale of both the technology and the decision-making is an important factor in determining ethical and social risks, because many climate strategies are relatively innocuous at small scale, but could be problematic at a larger scale. Because of this, a case-by-case approach to governance and incentivisation could be desirable, whilst improving understanding of the interactions between technologies. However, we emphasize that the conclusions drawn about how best to categorize, govern and incentivize any strategy will depend on the framing used, because different framings of the same conclusions could lead to very different policy recommendations. Most importantly, we argue that a robust, ethical approach to developing, governing and financing GGRsand in fact any large-scale technologically-advanced climate 
strategy-should pay urgent attention to concerns regarding democracy, justice and acceptability.

\section{AUTHOR CONTRIBUTIONS}

EC researched and wrote the manuscript. NP wrote sections of the manuscript, contributed to the formulation of the ideas and provided comments on drafts. ES and GT revised the paper and contributed to the formulation of ideas.

\section{REFERENCES}

Anderson, K. (2015). Duality in climate change science. Nat. Geosci. 8, 898-900. doi: 10.1038/ngeo2559

Anderson, K., and Peters, G. (2016). The trouble with negative emissions. Science 354, 182-183. doi: 10.1126/science.aah4567

Anshelm, J., and Hansson, A. (2014). Battling Promethean dreams and Trojan horses: revealing the critical discourses of geoengineering. Energy Res. Soc. Sci. 2, 135-144. doi: 10.1016/j.erss.2014.04.001

Asayama, S., Sugiyama, M., and Ishii, A. (2017). Ambivalent climate of opinions: tensions and dilemmas in understanding geoengineering experimentation. Geoforum 80, 82-92. doi: 10.1016/j.geoforum.2017.01.012

Beerling, D. J. (2017). Enhanced rock weathering: biological climate change mitigation with co-benefits for food security? Biol. Lett. 13:20170149. doi: 10.1098/rsbl.2017.0149

Bellamy, R., Chilvers, J., Vaughan, N. E., and Lenton, T. M. (2013). 'Opening up' geoengineering appraisal: multi-criteria mapping of options for tackling climate change. Glob. Environ. Change 23, 926-937. doi: 10.1016/j.gloenvcha.2013.07.011

Bellamy, R., and Lezaun, J. (2017). Crafting a public for geoengineering. Public Underst. Sci. 26, 402-417. doi: 10.1177/0963662515600965

Bellamy, R., Lezaun, J., and Palmer, J. (2017). Public perceptions of geoengineering research governance: an experimental deliberative approach. Glob. Environ. Change 45, 194-202. doi: 10.1016/j.gloenvcha.2017.06.004

Bickerstaff, K., Lorenzoni, I., Pidgeon, N. F., Poortinga, W., and Simmons, P. (2008). Reframing nuclear power in the UK energy debate: nuclear power, climate change mitigation and radioactive waste. Public underst. Sci. 17, 145-169. doi: 10.1177/0963662506066719

Buck, H. J. (2016). Rapid scale-up of negative emissions technologies: social barriers and social implications. Clim. Change 139, 155-167. doi: 10.1007/s10584-016-1770-6

Buck, H. J., Gammon, A. R., and Preston, C. J. (2014). Gender and geoengineering. Hypatia 29, 651-669. doi: 10.1111/hypa.12083

Cairns, R., and Stirling, A. (2014). 'Maintaining planetary systems' or 'concentrating global power?' High stakes in contending framings of climate geoengineering. Glob. Environ. Change 28, 25-38. doi: 10.1016/j.gloenvcha.2014.04.005

Campbell-Arvai, V., Hart, P. S., Raimi, K. T., and Wolske, K. S. (2017). The influence of learning about carbon dioxide removal (CDR) on support for mitigation policies. Clim. Change 143, 321-336. doi: 10.1007/s10584-017-2005-1

Cohen, J. J., Reichl, J., and Schmidthaler, M. (2014). Re-focussing research efforts on the public acceptance of energy infrastructure: a critical review. Energy 76, 4-9. doi: 10.1016/j.energy.2013.12.056

Corner, A., Parkhill, K. A., and Pidgeon, N. (2011). “Experiment Earth?” Reflections on a Public Dialogue on Geoengineering. Cardiff University Working Paper.

Corner, A., and Pidgeon, N. (2010). Geoengineering the climate: the social and ethical implications. Environ. Sci. Policy Sustain. Dev. 52, 24-37. doi: 10.1080/00139150903479563

Corner, A., and Pidgeon, N. (2014). Geoengineering, climate change scepticism and the "moral hazard" argument: an experimental study of UK public perceptions. Philos. Trans. A Math. Phys. Eng. Sci. 372:20140063. doi: $10.1098 /$ rsta.2014.0063

\section{ACKNOWLEDGMENTS}

This research was funded by a Leverhulme Trust project research grant, for the project The Leverhulme Centre for Climate Change Mitigation (LC3M; grant number: RC-2015-029). We would also like to thank the editors of this Special Issue, and all the reviewers whose constructive and insightful comments helped enormously to improve this paper. Further thanks go to our colleagues in the Understanding Risk research group for their ongoing support.

Cotula, L. (2009). Land Grab or Development Opportunity?: Agricultural Investment and International Land Deals in Africa. London: International Institute for Environment and Development.

Demski, C., Butler, C., Parkhill, K. A., Spence, A., and Pidgeon, N. F. (2015). Public values for energy system change. Glob. Environ. Change 34, 59-69. doi: 10.1016/j.gloenvcha.2015.06.014

Devine-Wright, P. (2011). Place attachment and public acceptance of renewable energy: a tidal energy case study. J. Environ. Psychol. 31, 336-343. doi: 10.1016/j.jenvp.2011.07.001

Devine-Wright, P., Walker, G., Barnett, J., Burningham, K., Infield, D., Devine-Wright, H., et al. (2009). Beyond NIMBYISM: A Multidisciplinary Investigation of Public Engagement With Renewable Energy Technologies: Full Research Report (ESRC End of Award Report No. RES-152-25-1008-A). Swindon: ESRC.

EASAC (2018). Negative Emissions Technologies: What Role in Meeting Paris Agreement Targets? (EASAC Policy Report No. 35). European Academies Science Advisory Council, Halle (Saale).

ETC Group Heinrich Böll Foundation (2017). Riding the Geostorm (A Briefing from Civil Society on Geoengineering Governance). Berlin; Ottawa, ON; ETC Group/Heinrich Böll Foundation.

Fleurke, F. (2013). A Brief Introduction to the Phenomenon of Land Grabbing. The Hague: VN Forum.

Fuss, S., Canadell, J. G., Peters, G. P., Tavoni, M., Andrew, R. M., Ciais, P., et al. (2014). Betting on negative emissions. Nat. Clim. Change 4, 850-853. doi: $10.1038 /$ nclimate2392

Gannon, K., and Hulme, M. (2017). Geoengineering at the 'Edge of the World': Exploring Perceptions of Ocean Fertilization Through the Haida Salmon Restoration Corporation (CCCEP Working Paper No. 316). Grantham Research Institute (London).

Gardiner, S. (2010). Climate Ethics: Essential Readings. Oxford: Oxford University Press.

Grainger, M., and Geary, K. (2011). The New Forests Company and its Uganda plantations (Oxfam Case Study). Nairobi: Oxfam International.

Gregory, R., Satterfield, T., and Hasell, A. (2016). Using decision pathway surveys to inform climate engineering policy choices. Proc. Natl. Acad. Sci. U.S.A. 113, 560-565. doi: 10.1073/pnas.1508896113

Hamilton, C. (2010). "Ethical anxieties about geoengineering: moral hazard, slippery slope and playing God," in Presented at the Conference of the Australian Academy of Science (Canberra).

Hansen, J., Sato, M., Kharecha, P., von Schuckmann, K., Beerling, D. J., and Cao, J., et al. (2017). Young people's burden: requirement of negative CO2 emissions. Earth Syst. Dyn. 8, 577-616. doi: 10.5194/esd-8-577-2017

Henwood, K., Pidgeon, N., Sarre, S., Simmons, P., and Smith, N. (2008). Risk, framing and everyday life: epistemological and methodological reflections from three socio-cultural projects. Health Risk Soc. 10, 421-438. doi: 10.1080/13698570802381451

Heyward, C. (2013). Situating and abandoning geoengineering: a typology of five responses to dangerous climate change. Polit. Sci. Polit. 46, 23-27. doi: $10.1017 /$ S1049096512001436

Ipsos Mori, (2010). Experiment Earth? Report on a public dialogue on geoengineering. Natural Environment Research Council (Swindon).

Jamieson, D. (2013). Some whats, whys and worries of geoengineering. Clim. Change 121, 527-537. doi: 10.1007/s10584-013-0862-9 
Lawford-Smith, H., and Currie, A. (2017). Accelerating the carbon cycle: the ethics of enhanced weathering. Biol. Lett. 13:20160859. doi: 10.1098/rsbl.2016. 0859

Lee, R. P., and Gloaguen, S. (2015). Path-dependence, lock-in, and student perceptions of nuclear energy in France: implications from a pilot study. Energy Res. Soc. Sci. 8, 86-99. doi: 10.1016/j.erss.2015.05.001

Lin, A. C. (2013). Does geoengineering present a moral hazard? Ecology LQ 40, 673-712

Lomax, G., Lenton, T. M., Adeosun, A., and Workman, M. (2015a). Investing in negative emissions. Nat. Clim. Change 5, 498-500. doi: 10.1038/nclimate2627

Lomax, G., Workman, M., Lenton, T., and Shah, N. (2015b). Reframing the policy approach to greenhouse gas removal technologies. Energy Policy 78, 125-136. doi: 10.1016/j.enpol.2014.10.002

Markusson, N. (2013). Tensions in Framings of Geoengineering: Constitutive Diversity and Ambivalence. Institute for Science, Innovation and Society, University of Oxford.

Markusson, N., and Haszeldine, S. (2009). 'Capture readiness'-lockin problems for CCS governance. Energy Procedia 1, 4625-4632. doi: 10.1016/j.egypro.2009.02.284

Markusson, N., McLaren, D., Tyfield, D., Jarvis, A., Willis, B., and Szerszynski, B. (2017). A False Promise? Lancaster: Lancaster University blog post.

McLaren, D. (2016). "Framing out justice: the post-politics of climate engineering discourses," in Climate Justice and Geoengineering: Ethics and Policy in the Atmospheric Anthropocene, ed Preston, C (Lanham, MD: Rowman and Littlefield,), 139-160.

McLaren, D., Krieger, K., and Bickerstaff, K. (2013). "Justice in energy system transitions: the case of carbon capture and storage," in Energy Justice in a Changing Climate: Social Equity and Low-Carbon Energy, eds K. Bickerstaff, G. Walker, and H. Bulkeley (London: Zed Books Ltd.), 158-181.

McLaren, D., Parkhill, K. A., Corner, A., Vaughan, N. E., and Pidgeon, N. F. (2016). Public conceptions of justice in climate engineering: evidence from secondary analysis of public deliberation. Glob. Environ. Change 41, 64-73. doi: 10.1016/j.gloenvcha.2016.09.002

Meadowcroft, J. (2013). Exploring negative territory Carbon dioxide removal and climate policy initiatives. Clim. Change 118, 137-149. doi: 10.1007/s10584-012-0684-1

Olson, R. L. (2011). Geoengineering for Decision Makers. Woodrow Wilson International Center for Scholars, Washington, DC.

Olson, R. L. (2012). Soft geoengineering: a gentler approach to addressing climate change. Environ. Sci. Policy Sustain. Dev. 54, 29-39. doi: 10.1080/00139157.2012.711672

Persson, J., Sahlin, N.-E., and Wallin, A. (2015). Climate change, values, and the cultural cognition thesis. Environ. Sci. Policy 52, 1-5. doi: 10.1016/j.envsci.2015.05.001

Pidgeon, N., and Demski, C. C. (2012). From nuclear to renewable: energy system transformation and public attitudes. Bull. At. Scientists 68, 41-51. doi: $10.1177 / 0096340212451592$

Pidgeon, N. F., Hood, C., Jones, D., Turner, B., and Gibson, R. (1992). Risk Perception, in: Risk-Analysis, Perception and Management. Report of a Royal Society Study Group. The Royal Society, London.

Pidgeon, N. F., and Spence, E. (2017). Perceptions of enhanced weathering as a biological negative emissions option. Biol. Lett. 13:20170024. doi: $10.1098 / \mathrm{rsbl} .2017 .0024$

Pidgeon, N., Kasperson, R. K., and Slovic, P. (2003). The Social Amplification of Risk. Cambridge; New York, NY: Cambridge University Press.
Porter, K. E., and Hulme, M. (2013). The emergence of the geoengineering debate in the UK print media: a frame analysis. Geogr. J. 179, 342-355. doi: 10.1111/geoj.12003

Preston, C. J. (2013). Ethics and geoengineering: reviewing the moral issues raised by solar radiation management and carbon dioxide removal: Clim. Change 4, 23-37. doi: 10.1002/wcc.198

Preston, C. J. (2015). Framing an ethics of climate management for the Anthropocene. Clim. Change 130, 359-369. doi: 10.1007/s10584-014-1182-4

Preston, C. J. (2016). Climate engineering and the cessation requirement: the ethics of a life-cycle. Environ. Values 25, 91-107. doi: 10.3197/096327115X14497392134964

Royal Society, (2009). Geoengineering the Climate: Science, Governance and Uncertainty. London: Royal Society.

Scheer, D., and Renn, O. (2014). Public perception of geoengineering and its consequences for public debate. Clim. Change 125, 305-318. doi: $10.1007 /$ s10584-014-1177-1

Shue, H. (2017). Climate dreaming: negative emissions, risk transfer, and irreversibility. J. Hum. Rights Environ. 8, 203-216. doi: 10.4337/jhre.2017.02.02

Stilgoe, J., Watson, M., and Kuo, K. (2013). Public engagement with biotechnologies offers lessons for the governance of geoengineering research and beyond. PLoS Biol. 11:e1001707. doi: 10.1371/journal.pbio.1001707

Stirling, A. (2010). Keep it complex. Nature 468, 1029-1031. doi: 10.1038/4681029a

Stirling, A. (2014). Emancipating Transformations: From Controlling "the Transition" to Culturing Plural Radical Progress. Climate Geoengineering Governance Working Paper series.

Tedsen, E., and Homann, G. (2013). Implementing the precautionary principle for climate engineering. Carbon Clim. Law Rev. 7, 90-100. doi: 10.21552/CCLR/2013/2/250

United Nations (1992). United Nations Framework Convention on Climate Change (No. FCCC/INFORMAL/84). Bonn: United Nations.

Unruh, G. C., and Carrillo-Hermosilla, J. (2006). Globalizing carbon lock-in. Energy Policy 34, 1185-1197. doi: 10.1016/j.enpol.2004.10.013

Wibeck, V., Hansson, A., Anshelm, J., Asayama, S., Dilling, L., Feetham, P. M., et al. (2017). Making sense of climate engineering: a focus group study of lay publics in four countries. Clim. Change 145, 1-14. doi: 10.1007/s10584-017-2067-0

Williamson, P., and Bodle, R. (2016). Update on Climate Geoengineering in Relation to the Convention on Biological Diversity: Potential Impacts and Regulatory Framework (CBD Technical Series No. 84). Secretariat of the Convention on Biological Diversity, Montreal, QC.

Wong, P.-H. (2014). Maintenance required: the ethics of geoengineering and post-implementation scenarios. Ethics Policy Environ. 17, 186-191. doi: $10.1080 / 21550085.2014 .926090$

Conflict of Interest Statement: The authors declare that the research was conducted in the absence of any commercial or financial relationships that could be construed as a potential conflict of interest.

The reviewer, DM, and handling editor declared their shared affiliation.

Copyright (c) 2018 Cox, Pidgeon, Spence and Thomas. This is an open-access article distributed under the terms of the Creative Commons Attribution License (CC $B Y)$. The use, distribution or reproduction in other forums is permitted, provided the original author(s) and the copyright owner are credited and that the original publication in this journal is cited, in accordance with accepted academic practice. No use, distribution or reproduction is permitted which does not comply with these terms. 